\title{
Scientific Consequentialism: Potential Problems with an Outcome-Driven Form of Indigenous Archaeology
}

\author{
Deborah H. Williams ${ }^{1,2}$, Gerhard P. Shipley ${ }^{3}$ \\ ${ }^{1}$ Department of Environmental Science, Johnson County Community College, Overland Park, Kansas, USA \\ ${ }^{2}$ Department of Anthropology, University of Kansas, Lawrence, Kansas, USA \\ ${ }^{3}$ University of Kansas, Lawrence, Kansas, USA \\ Email: Research_Studies@outlook.com
}

How to cite this paper: Williams, D. H., \& Shipley, G. P. (2020). Scientific Consequentialism: Potential Problems with an Outcome-Driven Form of Indigenous Archaeology. Archaeological Discovery, 8, 63-83. https://doi.org/10.4236/ad.2020.81004

Received: October 20, 2019

Accepted: November 16, 2019

Published: November 19, 2019

Copyright $\odot 2020$ by author(s) and Scientific Research Publishing Inc. This work is licensed under the Creative Commons Attribution International License (CC BY 4.0).

http://creativecommons.org/licenses/by/4.0/

\section{cC) (i) Open Access}

\begin{abstract}
"Scientific consequentialism" is the position that the rightness and wrongness of scientific research and reporting is determined by its effects on individuals or groups, rather than by its adherence to the ideals of the scientific method. Indigenous archaeology asserts that archaeology ought to be performed "with, by, and for" indigenous peoples, and in its reasonable form, Indigenous archaeology is important to making Western science more respectful of Indigenous concerns and more applicable to studying peoples with metaphysically inclusive worldviews. However, some proponents advocate for an extreme, consequentialist form of "for" which seeks to limit scientists to research and results that serve and benefit Indigenous peoples' social and political interests. This may include suppressing undesirable research or results, manipulating scientists or the scientific process, and avoiding research into certain subjects, all of which are presented as morally required efforts toward "the good" of decolonization. This extreme, outcome-driven form of Indigenous archaeology is irreconcilable with and even antithetical to the ideals of Western science, risks unintended negative consequences over the long term, and is no more appropriate now to support decolonial agendas than were consequentialist efforts in the past to support colonial agendas.
\end{abstract}

\section{Keywords}

Scientific Consequentialism, Archaeology, Indigenous Archaeology, Decolonize

\section{Introduction}

Ethical consequentialism asserts that the rightness and wrongness of actions are 
determined by their effects with regard to achieving some standard of "the good" (e.g., happiness). Scientific research is an action and is therefore subject to consequentialist evaluation based on its effects on individuals or groups. Deontology is the primary alternative to consequentialism, and it asserts that actions are right insofar as actors (e.g., scientists) adhere to their duty to some ideal and wrong otherwise, regardless of the consequences. Most scientists follow a deontological paradigm in that they attempt to adhere as much as possible to the ideals of the scientific method and accept the results without regard to the potential effects.

In Western culture, science and scientists are highly respected and the ethical foundation of the modern scientific endeavor is largely unquestioned. In at least some social science disciplines, however, there is a growing push for scientific consequentialism. In archaeology, for example, there is growing support for "Indigenous archaeology" which asserts that archaeology ought to be performed "with, by, and for" Indigenous peoples in order to do less harm and provide greater benefits. The limits of "with, by, and for" are still evolving, and while the literature includes "win-win" examples in which Indigenous peoples work closely with scientists and willingly contribute to, greatly enhance, and benefit from research, there is little discussion of more problematic situations in which Indigenous peoples reject research or results which may negatively affect their social or political interests.

On the one hand, we agree that the scientific process far too often ignores the concerns of and effects on its subjects and other stakeholders, and would be improved by increased communication and collaboration. Elsewhere, we have discussed the limitations of the Western scientific worldview for the study of metaphysically inclusive peoples, and identified Indigenous archaeology as a useful approach for overcoming at least some of those limitations (Shipley \& Williams, 2019). On the other hand, we believe that these efforts can be taken too far. Some proponents of Indigenous archaeology seem to advocate for an extreme, consequentialist form of "for" which seeks to limit scientists to research and results that serve and benefit Indigenous peoples' social and political interests. This may include suppressing undesirable research or results, manipulating scientists or the scientific process, and avoiding research into certain subjects, all of which are presented as morally required efforts toward "the good" of decolonization. While well-intended, such an outcome-driven paradigm to further Indigenous interests is ethically indistinguishable from past efforts to manipulate scientific research and results to further colonial interests and "the (then) good" of colonization.

This paper examines the rise of scientific consequentialism and potential problems with this extreme, outcome-driven form of Indigenous archaeology. Our presentation necessarily includes a number of problematic quotes from the literature which gave rise to our concern. To the obvious criticism that we have taken these quotes out of context to make our case, we respond that no context can make them reasonable and the writers should have been more thoughtful in 
crafting the language they used to express their positions. In its extreme form, Indigenous archaeology is irreconcilable with and even antithetical to the ideals of Western science, and we conclude that such manipulation risks unintended negative consequences over the long term and is no more appropriate now to support decolonial agendas than it was in the past to support colonial agendas.

\section{Archaeology as a Colonial Endeavor}

Archaeology emerged as an aspect of a larger colonial desire to conquer unknown worlds (Smith \& Jackson, 2006). Artifacts provided proof of conquest, and the subjugation of Indigenous cultures through research and representation was a manifestation of colonial control (Smith \& Jackson, 2006). Modern archaeology inherited this deeply colonial legacy (Atalay, 2006; Smith \& Jackson, 2006). Indigenous peoples have often been at odds with archaeologists over their relationship and about who should have control over research questions and designs, how data should be interpreted and used, and how ancestors and their communities should be represented (Watkins, 2003). Due to Western society's emphasis on formal education and the authority of scientists, archaeologists are considered to have knowledge that is somehow beyond the understanding of nonscientists, and so they assume final authority with regard to the archaeological record (Watkins, 2003). As a result, "members of descendant communities often feel powerless about what happens to their ancestors and the archaeological sites associated with them", and they perceive archaeologists to be arrogant and insensitive, even as archaeologists perceive them to be antagonistic toward research (Watkins, 2003: p. 273).

An example of the ongoing colonial perspective in archaeology is the pervasive negative characterization and treatment of the oral histories of Indigenous peoples. Many archaeologists are reluctant to share power and authority over how the past is studied and represented (Watkins, 2003), and this is manifested in their dismissal of Indigenous knowledge (Steeves, 2015). Written histories are viewed as detached, objective, and reliable, while oral histories are viewed as changeable, subjective, and unreliable and have little or no value in the Western scientific worldview (Smith \& Jackson, 2006). This scientific colonialism-this failure to include Indigenous peoples as equals in the stewardship of their own past-excludes them from discourse that is ultimately about them (Watkins, 2003).

As long as Indigenous peoples are treated not as research partners but as "objects" of scientific inquiry under policies that privilege Western ontology and epistemology, the scientific study of Indigenous peoples will continue to be a colonial and conflict-laden endeavor. "[F]undamental differences in epistemology must be acknowledged in order to truly understand the conflicts between scientists and indigenous peoples" (Tsosie, 2015: p. 1140). Western science and Native American spirituality must be balanced in a way that recognizes the validity of both, and in order to achieve that balance, "archaeology must accept the validity of Native American spiritual beliefs and practices, particularly with re- 
gard to burials and sacred objects" (White Deer, 1998: p. 336). However, archaeology has never seriously considered the spirituality of Indigenous peoples as relevant to its own concepts and practices (White Deer, 1998). As a result, Western scholarship has been characterized as "simply another kind of imperialism that re-inscribes existing structures of power" (Lee, 2010: p. 33), and "science ... [which] is the dominant discourse of archaeology ... simultaneously reinforces the authority of the academy and the subservient positioning of Indigenous peoples" (Smith \& Jackson, 2006: p. 314).

\section{Indigenous Archaeology}

By the mid-twentieth century, Indigenous people's protests over the excavation, collection, and display of their cultural and ancestral remains by archaeologists and their demands to have more control over their own heritage could no longer be ignored, and archaeology was forced to begin examining its interactions and relationships with Indigenous peoples (Atalay, 2006). Increasing self-reflection along with the influence of postmodernism led to the recognition that archaeology, like most human endeavors, is strongly shaped by the social and political contexts in which it is practiced (Atalay, 2006). Today, debate continues over the injustices of research practices that do not benefit Indigenous peoples and that exploit these remains, and over the larger question of who should have the power to speak for and write the stories of the past (Atalay, 2006). Because archaeology supported or, at least, was used to support many of the stereotypes of colonialism, "Indigenous peoples have a right to expect archaeologists to assist with the decolonization of archaeology" (Smith \& Jackson, 2006: p. 312). Just as colonialism violently transformed and erased the identities of Indigenous peoples, decolonizing knowledge production must work to un-erase them (Steeves, 2015). In that light, "[t]he trajectory of Indigenist research is clearly focused on directions of decolonizing, re-writing, re-claiming, and self-determination along paths of 'post-colonial' healing in a 'neo-colonial' world" (Steeves, 2015: p. v). This includes finding ways to create counter-discourses that challenge the colonialist and imperialist interpretations of the past (Atalay, 2006).

Indigenous archaeology arose and continues to evolve as a response to postcolonial critiques of archaeological practices, particularly the privileging of Western perspectives (McNiven, 2016). It has emerged as a new form of archaeology that is informed by Indigenous values and agendas (Wobst, 2010) and that "is in synch with and contributes to the goals, aims, hopes, and curiosities of the communities whose past and heritage are under study, using methods and practices that are harmonious with their own worldviews, traditional knowledges, and lifeways" (Atalay, 2006: p. 284; see also Nicholas, 2008). In actual practice, Indigenous archaeology can mean different things, and what is considered Indigenous archaeology in one region might not be applicable to other regions (Watkins, 2010). Thus, because Indigenous archaeology is a broad approach that can be applied in different ways, it may be better conceived of as Indigenous archaeologies (Colwell-Chanthaphonh et al., 2010). 
According to Nicholas (2008), Indigenous archaeology has the goals of making archaeology more representative of, responsible to, and relevant for Indigenous communities; redressing real and perceived inequalities in the practice of archaeology; and informing and broadening the understanding and interpretation of the archaeological record through the incorporation of Indigenous worldviews, histories, and science. This may be accomplished by any of the following: The active participation or consultation of Indigenous peoples in archaeology; a political statement concerned with issues of Indigenous self-government, sovereignty, land rights, identity, and heritage; a postcolonial exercise to decolonize the discipline; a manifestation of Indigenous epistemology; a basis for alternative models of cultural heritage management or stewardship; the product of choices and actions by individual archaeologists; a means of empowerment and cultural revitalization or political resistance, and an extension, evaluation, critique, or application of current archaeological theory.

Atalay (2006: p. 301) characterized Indigenous archaeology as "a collaborative approach that blends the strengths of Western archaeological science with the knowledge and epistemologies of Indigenous peoples to create a set of theories and practices for an ethically informed study of the past, history, and heritage". Unlike mere consultation, collaboration allows Indigenous peoples to play an active role in the entire research process, including research design, grant writing and funding processes, results analysis and interpretation, and report production. Silliman (2008) similarly called for collaboration in which archaeologists consider Indigenous perspectives throughout their projects, from project formulation, development, initiation, data recovery, laboratory analysis, data evaluation and interpretation, and report writing, to project shutdown. Cipolla, Quinn, and Levy (2019) also espoused co-authorship of publications, and expressly categorized each of its co-authors as either settler-colonist or Indigenous. For Croes (2010: p. 211), collaboration is "a 50/50 partnership between the archaeological scientist and the native people", which "means, and allows, joint ownership that can only expand the scientific description and the cultural explanation through an Indigenous archaeology". For McNiven (2016: p. 28), quoting George (2010: p. 105), collaboration often begins with archaeologists asking Indigenous leaders "what sort of research, if any, they would be interested in hosting and 'what they would like others to know about their community and culture", so that Indigenous archaeology is archaeology for and not simply about Indigenous people. Thus, Indigenous archaeology includes an element of "mutuality" in fieldwork and in the interpretation and presentation of results, "and co-accommodation of Western and Indigenous [worldviews]" (McNiven, 2016: p. 28).

\section{"With, By, and For"}

Perhaps the most accepted characterization of Indigenous archaeology is as a decolonized archaeological paradigm that is "with, by, and for" Indigenous 
peoples (see, e.g., Atalay, 2006; Colwell-Chanthaphonh et al., 2010; Nicholas, 2001; Nicholas \& Andrews, 1997; Silliman, 2010 citing Nicholas, 2008). Archaeology "with" Indigenous peoples involves close collaboration, and gives Indigenous stakeholders a voice in how the work is performed (Silliman, 2010). Archaeology "by" Indigenous peoples introduces much needed diversity into the discipline by encouraging participation, providing support for educational and career paths, recognizing sovereignty, prioritizing community, and respecting their knowledge and concerns about history (Silliman, 2010). Archaeology "by" Indigenous scholars and communities is research in which they have power and are in control of the design and interpretations, and in which "research is a ceremony" with the purpose of raising consciousness and developing insight into the world (Wilson, 2008: p. 11). Archaeology "for" Indigenous peoples ensures that research projects acknowledge and address the troubled history of archaeology's treatment of Indigenous peoples, including by telling useful, respectful, and peopled histories that resonate with communities' senses of themselves and their particular needs (Silliman, 2010).

Decolonizing archaeology involves accepting alternative ways of viewing the past as equally valuable and legitimate ways of knowing (Atalay, 2006). Further, Indigenous discourse challenges academic hegemony and its privileging of non-Indigenous written sources in knowledge production of the Indigenous past to accept oral histories as valid data (Steeves, 2015). Adding Indigenous perspectives to our understanding of the past is essential to decolonizing narratives and minds (Steeves, 2015) and creating a more representative past (Nicholas, 2001). So for many Indigenous scholars, methodology begins with a study of relevant oral traditions (Steeves, 2015). “This need not undermine archaeology's commitments to studying parts of the past in rigorous and scientific ways, nor must it produce 'proprietary histories', particularly when done collaboratively" (Silliman, 2010: p. 218). In this manner, Indigenous archaeology seeks to achieve a more respectful dialogue between various stakeholders, of which archaeologists are only one (Silliman, 2010).

Watkins (2010) discussed the positive impact of Indigenous archaeology on several areas of archaeological practice. Indigenous archaeology can provide relational benefits in that it allows archaeologists to improve relationships with stakeholders, because "the more we include local and Indigenous perspectives within our research, the more we create support for what we do" (Watkins, 2010: pp. 54-55). Indigenous archaeology can also have an operational impact in that as archaeologists include more stakeholders they relinquish some control over the way in which archaeology is practiced. While the process will be changed, the sharing of information and the gathering of alternative perspectives will expand and benefit archaeology rather than harm it:

Generally speaking, we will give up portions of our control over the archaeological record. We will sometimes be forced to ask permission to operate within arenas that previously we took as our own. We will have personality 
conflicts and programmatic lapses. We will shake our heads at interpretations and representations, but I believe archaeology will survive and become stronger

(Watkins, 2010: p. 58).

In response to archaeologists who argue that the discipline should try to remain more objective, Watkins noted that archaeology never has been and never can be completely apolitical or neutral. If archaeologists continue to insulate themselves from stakeholders who see themselves as the social, political, or cultural stewards of the archaeological record or cultural heritage, then archaeology will continue to be a sterile act serving only the needs of one group of people as a handmaiden of colonialism (Watkins, 2010). Having said that, Indigenous archaeology is not meant to replace scientific archaeology but to add to archaeology's interpretative power (Watkins, 2010). For example, archaeologists tend to focus on the physical, technological, and esoteric attributes of artifacts, while Indigenous peoples are often more interested in the ceremonial and social importance of the same artifacts, so Indigenous archaeology attempts to consider all of these aspects of artifacts and thereby serve the needs of all stakeholders (Watkins, 2005).

\section{Critical Debate of Indigenous Archaeology}

McGhee (2008) raised the concern that Indigenous archaeology is based on Aboriginal essentialism ("Aboriginalism") and the notion that Indigenous peoples possess fundamentally different qualities from non-Indigenous peoples. McGhee (2008: p. 581) also asserted that some proponents seek "to appease Indigenous opposition by incorporating non-Western values and perspectives as sources and methods of investigation, or by explicitly aligning their efforts with the historical interests of specific communities or groups". Such efforts are not only theoretically unsound, but can be harmful both to archaeology and to Indigenous communities, and they allow Indigenous peoples to assert exclusive rights over knowledge that are not available to non-Indigenous peoples (McGhee, 2008).

McGhee (2008: p. 582) characterized proponents as viewing archaeology as being "an instrument of a coercive state", and as serving "to deprive Indigenous peoples of their right to define their own place in the modern world, and [as] an effective weapon of assimilation to mainstream cultures". For example, Custer (2005: p. 3) asserted that "archaeologists have created a thought world which serves to support their own power and privilege, harms the interests of American Indian people, and aids the ongoing cultural genocide focused on Native Americans". Because traditional archaeology is characterized in such extreme terms, anyone attempting to question the concept of Indigenous archaeology is by implication unethical or even criminal (McGhee, 2008). The proposed solution is to "depart radically from the practice of archaeology as an academic and heritage management discipline" (McGhee, 2008: p. 591). For example:

Some (Custer, 2005) argue that archaeology can be practiced with a clear con- 
science only if it is carried out at the request of, and under the direction and control of, an Indigenous community. Others simply assume that "Indigenous rights should always trump scientific inquiry" as Gillespie (2004: p. 174) notes of the papers collected by Zimmerman[, Vitelli, \& Hollowell-Zimmer] (2003) ... McNiven \& Russell (2005: p. 239) see the claims of archaeologists to academic freedom as no more than "part of the colonial fantasy of naturalized superiority and hegemonic control.” ... McNiven \& Russell (2005: p. 236) propose that archaeologists accept a "host/guest" relationship with Indigenous communities, which "have every right to control archaeological research in whatever way they wish" (McGhee, 2008: pp. 591-594, emphasis added).

McGhee is not alone in questioning such extreme positions. Kuper (2003: p. 400) noted that if anthropologists become "the academic wing of the indigenous rights movement" then their works will be worthless except as propaganda. Trigger (1997: p. x) warned that "[f]or archaeologists to take sides in political issues of this sort risks interference in Native life that may be scarcely less patronizing than the interference of Indian agents and missionaries was in the past". Smith (2004) noted that Indigenous archaeology inserts the discipline into political negotiations between Indigenous and colonial peoples. In particular, Indigenous peoples' historical assertions are part of wider negotiations with governments about the legitimacy of Indigenous claims to specific rights, not least of which are rights to land. The consequences of supporting statements and perspectives which are consistent with the beliefs of Indigenous peoples but not with scientific evidence and of "accommodating a scientific discipline to the desires of a specific nonscientific community are not at all clear" (McGhee, 2008: p. 592).

Croes (2010: p. 215) acknowledged the potential problems identified by McGhee, but asserted that archaeologists should "approach this work as a true $50 / 50$ partnership with tribes, to the mutual benefit of both sides in the shared objectives". Croes gave examples of cooperative efforts, but all were "win-win" scenarios that did not involve difficult questions. For example, Croes asserted that the applied aspect of archaeology needs to be part of the process of improving the quality of lives of stakeholders, and told a story of how archaeological research helped a particular Indigenous group to more beneficially define its treaty rights regarding harvesting shellfish in their traditional area. However, Croes did not discuss the possibility that research might have shown their traditional area to be significantly smaller than the group was asserting. It is unclear whether or how Croes's respectful and facilitative partnership approach would work in cases in which results are not beneficial or flattering or in which they contradict oral histories or spiritual beliefs.

Colwell-Chanthaphonh et al. (2010) rejected McGhee's charge of essentialism, and argued that McGhee was simply pitting science as a pure objective positivist pursuit against Indigenous peoples as eco-spiritual subjectivists. Wilcox (2010) also argued against the dichotomization of scientific and Indigenous archaeologies. Silliman (2010: p. 219) similarly rejected McGhee’s position as “[working] 
against the postcolonial aims supported by most Indigenous archaeologists who seek to interrogate, repair, and hopefully move beyond the colonial origins of the discipline and its treatment of Native people". Silliman asserted that Indigenous archaeology attempts to mitigate the negative effects of archaeological practice on the living descendants of subject communities and also attempts to benefit from those descendants' contributions to knowledge of the past. It does this "simultaneously, successfully, and rigorously without 'strip[ping] archaeology of the scientific attributes that make it a particularly powerful narrator of the past"' (Silliman, 2010: p. 218, quoting McGhee, 2008: p. 591).

\section{The Extreme Form of "For"}

We disagree with those who reject even the more reasonable form and positive aspects of Indigenous archaeology, and we disagree with those who reject the fact that the Indigenous worldview differs from the Western scientific worldview. Our criticism is not of Indigenous archaeology in general, the benefits of which we think are obvious, but of an extreme, outcome-driven form which seems to involve not the integration of views or equalization of power but merely a transfer of privilege and power:

If colonialism has meant Indigenous peoples living within a framework of non-Indigenous control, the decolonization of archaeology has to involve archaeologists working within a framework of Indigenous control ... Given that differential access to power is at the core of colonial relations, it follows that the decolonization of Indigenous archaeology involves a rethinking of power relations between archaeologists and Indigenous peoples. It must involve a movement from the colonial assumption of a right to acquire knowledge to recognition of Indigenous peoples' rights to protect their cultural and intellectual property and to share knowledge on their own terms (Smith \& Jackson, 2006: p. 341, emphasis added).

In its more reasonable form, Indigenous archaeology prioritizes research that is relevant to Indigenous peoples, but in its more extreme form, it requires that research "benefit" them. For example, Steeves (2015: p. 29) claimed that "[m]any Indigenous people believe that knowledge gathered as a practice of gathering is a waste of time", which reflects the notion of relevance, but Louis (2007) went further and asserted that research that does not benefit the community and extend the quality of life of its members should not be done. The requirement to benefit already implicates scientific consequentialism, but some have argued that scientific research that is "for" Indigenous peoples should have the consequence of furthering the social and political interests of Indigenous peoples. For example, Ucko (2001: p. 1) noted a lack of awareness in the discipline "of the socio-political contexts of the practice and nature of archaeology in all parts of the world". In particular:

[Archaeologists] bring consequences to the societies involved which may be

far removed from that initially assumed by the archaeologist ... [I]t behooves 
archaeologists to understand how knowledge of the past, and of the present of "Others", not only plays a part in the social, political, and economic relations of people in the present, but will undoubtedly also do so in the future (Ucko, 2001: pp. 8-9, emphasis added).

Ucko (2001) did not expressly call for avoiding certain consequences or pursuing others, but it is implicit in his call to understand that research has consequences that some action should follow based on that understanding.

According to Nicholas (2001), Australian archaeologists who wish to perform research on the lands of Indigenous peoples must not only obtain permission but may have to relinquish certain rights to their research results. "While the initial reactions of prospective researchers are often negative, the reality is that the provisions are ones that most can abide, with little if any real restrictions on what they would have done otherwise" (Nicholas, 2001: p. 36). Nicholas gave no discussion of why these restrictions are needed if they have "little if any real" effect on archaeologists' work. Nicholas also suggested that the "for" aspect encompasses how science approaches research which contradicts the Indigenous worldview: The Western scientific worldview "threatens the integrity of the [Indigenou] worldview and beliefs", and "many [Indigenous] peoples are satisfied with their knowledge of the past as it is now; they don't need archaeology to tell them what they already know; to challenge this may be tantamount to dismissing their religious beliefs" (Nicholas, 2001: p. 30). Nicholas (2001: p. 31) did admit that " $[t]$ here is a strong desire by some [Indigenous] peoples to use the archaeological record to document cultural continuity, and to identify the material culture of specific cultural groups to support land claims", but did not discuss whether or how to accommodate them. So again, while this is not an express call to manipulate science to achieve particular ends, it begs the question of why archaeologists should be aware of such issues and the related "strong desires" of Indigenous peoples if not to do something to support them, and the question of what happens when research results disappoint. If Indigenous peoples control the rights to results, then it is at least possible that adverse results would be suppressed, in which case researchers would be tempted to either avoid such research altogether or ensure that the results are not adverse.

Steeves (2015) made an appeal to archaeologists and other scientists to actively use science to heal what Duran (2006: pp. 15-16) referred to as the "soulwounds" (i.e., intergenerational traumas) of Indigenous peoples, including "identity erasure, created in part through archaeologically cleaved links to ancestral places and times due to colonization". Rigney (1999: pp. 117-118, emphasis added) brazenly asserted that research should "serve and inform the political liberation struggle", and "it must be overtly political'. Even Atalay (2006: p. 296, emphasis added) seemed to accept that the extreme form of Indigenous archaeology involves transferring power from one stakeholder to another:

If in working to de-center some of the problematic aspects of Western archaeological practice, are we then advocating for destroying one power struc- 
ture (a Western one) to simply replace it with another, Indigenous-centered one? I ask this question because of a recent dialogue I had on this topic in which by suggesting the de-centering of Western concepts in order to center Indigenous views, I was labeled a "colonist", someone who was doing nothing different than what Western scholars had done before me (i.e., forcing my Indigenous worldview onto others) ... [W]e must sometimes use the master's tools ... to create a counter-discourse to Western approaches that have consistently worked to destroy or silence our Indigenous ways of knowing.

If "archaeological and historical data are not merely neutral pieces of information [and are] fundamentally fouled with political and neocolonial views and ideas" (Steeves, 2015: p. 48), then the question becomes whose political and neocolonial ideas will it reflect: Colonial or Indigenous? According to Steeves (2015: p 45, p. 85, emphasis added), "Indigenous archaeology ... is a political act focused on reclaiming control of the Indigenous past in the present ... [it is] carried out with and for Indigenous people ... Political control of cultural information is critical to the survival and protection of Indigenous peoples rights and sovereignty".

\section{Examples of Potential Problems with Scientific Consequentialism}

The extreme, outcome-driven form of Indigenous archaeology seems to require that scientific research and results have the effect of furthering Indigenous peoples' social and political interests. Of course, it would be difficult or impossible to know of research that has actually been suppressed, manipulated, or avoided, but the following examples show how strong the pressure of scientific consequentialism can be in at least attempting to suppress undesirable research or results, manipulate scientists and the scientific process, and altogether avoid research into certain subjects.

\subsection{Suppressing Undesirable Research or Results}

It seems unlikely that many Native Americans desire to know whether their ancestors practiced cannibalism, and the knowledge is unlikely to benefit them and could undermine their interests. Therefore, presumably either such research would not be pursued or, if it is, positive results would be suppressed under the extreme, consequentialist form of Indigenous archaeology. In fact, cannibalism has emerged as one of the most controversial issues in the archaeology of the American southwest. Billman, Lambert, \& Leonard (2000) reported on the remains of seven individuals exhibiting butchering marks and exposure to high heat, associated tools with blood residue, and a human coprolite containing human myoglobin which provide strong evidence of the preparation and consumption of human flesh. This and a number of similar finds in the region indicate a sharp increase in cannibalism around 1150 A.D., which corresponds with drought and the collapse of the Chaco system. Billman, Lambert, and Leonard 
hypothesized that faced with severe environmental stress, food scarcity, and sociopolitical upheaval, some groups used violence to terrorize or even eliminate others, and cannibalism was part of this violence. In reporting this research, their expressed goal was "to move the debate from the issue of whether or not cannibalism occurred ... to questions of broader anthropological significance", including the causes of cannibalism (Billman, Lambert, \& Leonard, 2000: p. 146).

However, some associate the assertion of cannibalism with the charge of "savagery", which historically was used to differentiate the uncivilized "other" and legitimize treating "them" as inferior (Arens, 1979). Dongoske, Martin, and Ferguson (2000: p. 180) asserted that the word "cannibalism" "carries some very heavy historical and emotional baggage", including helping "to ideologically pave the way for the eventual campaign of conquest, Christianization, and genocide that followed" (citing Barreiro, 1992: p. 35, but failing to acknowledge that Barreiro admitted that cannibalism did occur). Kilgour (1998: p. 240) similarly asserted that cannibalism was a symbol of the tools of oppression used by a guilty imperial past, "be it the British empire or the empire of anthropology", and Arens (1979) claimed that much of the literature on cannibalism is a meta-myth created as a means of boundary definition in the construction of Western identity. "These matters are not merely historical or theoretical: Indians must contend with negative stereotypes every day, in every arena of their lives. So ... claims for cannibalism must seem like one more attempt to denigrate Indians" (Morrow \& Lekson, 1999: p. 6). Even if the assertions are made by disinterested scientists based on objective evidence, they may be picked up and used by others to support racist positions (Morrow \& Lekson, 1999). Thus, "any characterization of Indians as 'cannibals' dredges up a long history of oppression and racism, and we have to realize that this may generate ill-will and negative emotions about archaeology in many descendant communities" (Dongoske, Martin, \& Ferguson, 2000: p. 180).

Dongoske, Martin, \& Ferguson (2000: pp. 180-181, emphasis added) did allow that "this does not mean that [cannibalism] is a forbidden subject for investigation but that its investigation must meet the most rigorous scientific standards possible ... our research must be unassailable ... there should be incontrovertible archaeological evidence of its existence". However, developing evidence and consensus requires open debate across multiple studies, so requiring that there be no open discussion of cannibalism until and unless it can be supported by unassailable and incontrovertible evidence is an impractical if not impossible standard, the result of which would be to effectively suppress research on the issue altogether. Further, Dongoske, Martin, and Ferguson criticized Billman, Lambert, and Leonard for not using ethnographic and ethnohistoric evidence to either support their conclusion of cannibalism or propose alternative explanations for the data, but provided no discussion of how such evidence might have resulted in a different interpretation of the data. They did attempt to fabricate an example alternative interpretation that does not involve cannibalism, but in doing 
so they distorted or outright ignored much of the evidence. Ironically, they argued that "[i]f archaeology is to be taken seriously by other scientists, rigorous adherence to scientific protocol is needed", but then claimed that they do "a different kind of science, one that is inclusive of a number of different points of views and perspectives" (Dongoske, Martin, \& Ferguson, 2000: p. 189, emphasis added). Ultimately, their concern was not whether past peoples actually engaged in cannibalism, but rather the potential consequences to modern peoples and their interests of openly acknowledging it:

Needless to say, the appropriation of the Cowboy Wash study by the popular press in complete disregard of the descendant communities was a damaging set back to all of us working in the Southwest. We know because many of our Native American colleagues have told us so ... We also are concerned with how allegations of cannibalism in the popular press affect contemporary Native Americans ... Historically, science and archaeology have been used to denigrate and dehumanize Native Americans, justifying the taking of land and the perception of Native American cultures as static and destined for extinction ... We think the sensationalistic approach to reporting claims of cannibalism inadvertently encourage racist views in American society (Dongoske, Martin, \& Ferguson, 2000: p. 188).

\subsection{Manipulating the Scientific Process}

Origin is a key qualitative distinction between the Indigenous and the colonial, and is often argued as a basis for the former's claims against the latter. Therefore, Indigenous peoples' assertions of originating in the Americas, or, at least, arriving much earlier than Europeans, presumably would be supported under the extreme, consequentialist form of Indigenous archaeology. For example, Deloria (1995: p. 84, emphasis in original) claimed that "[b]y making us immigrants to North America, [scientists] are able to deny the fact that we were the full, complete, and total owners of this continent ... and therefore throw back at us the accusation that we had simply found North America a little earlier than they had". Deloria (1992: p. 597, emphasis added) further argued that Native Americans will never be accorded full humanity until and unless they "are in some way connected with world history as early peoples, perhaps even as refugees from Old World turmoils and persecutions. We cannot be primitive peoples who were suddenly discovered half a millennium ago. The image and interpretation are all wrong ..." Thus, accepting that Indigenous peoples have been in the Western Hemisphere for over 60,000 years and possibly over 100,000 years puts them on equal footing with other peoples (Steeves, 2015). Establishing such a long tenure is important because it "impacts the social and political lives of contemporary people" (Steeves, 2015: p. 4, citing Gnecco, 2011) by solidifying their claims to Indigeneity and supporting Indigenous ownership of their past, their culture, and their lands (McNiven \& Russell, 2005; Steeves, 2015).

With that in mind, Steeves (2015) argued for a pre-Clovis, deep-time entry or 
outright origin of Natives in the Americas based on a number of controversial sites. Steeves (2015: pp. 76-77) referred to the Clovis First hypothesis, which was, at the time, the consensus hypothesis for the peopling of the Americas, as "the greatest myth ever told". Adovasio and Page (2002: p. xviii) similarly characterized it as "not logical" and "more like religious dogma". Steeves asserted that this myth was only able to become so deeply embedded in the dominant discourse because archaeologists delegitimized and erased the true Indigenous histories. Steeves (2015: p. 27) embraced Deloria's politicized approach to the issue and suggested that the claim of a more recent origin is nothing more than a deliberate attempt "to erase or marginalize the historical identities or even the historical presence of various groups whose historical consciousness may lead to claims to land, resources, and distinctive identities, all substantive challenges to colonial ownership, privilege, and production of historical knowledge". In an open attempt to coerce researchers, Steeves (2015: p. iv, emphasis added) argued that to deny an ancient tenure in the Americas is to commit a violence against Native Americans, and that "archaeology has an ethical and moral duty to un-erase histories and identities that its academic predecessors erased through violent discursive processes of knowledge production". Ironically, Clovis First is no longer the consensus hypothesis as somewhat older sites are now generally accepted (see, e.g., Waters \& Stafford, 2014), but this shift occurred because science stayed true to its ideals and worked properly to self-correct by continually considering new and reconsidering old evidence, not because Steeves had successfully coerced them into accepting an unsupported position (and, importantly, the now generally accepted pre-Clovis sites are still nowhere near the age required to support Steeves' position).

\subsection{Avoiding Research into Certain Subjects}

As discussed, long tenure would strengthen arguments for claims to the Western hemisphere as well as for more specific claims to tribal lands. Evidence of a shorter tenure or, alternatively, the long-term presence of non-Native Americans could weaken those claims. Therefore, Indigenous peoples' demands not to conduct research which might produce such undesirable evidence presumably would be respected under the extreme, consequentialist form of Indigenous archaeology. The case of "Kennewick Man" illustrates how adversarial the conflict between scientists and Indigenous peoples can become and both why a reasonable form of Indigenous archaeology is needed and why an extreme form must be avoided.

Human remains were discovered on federal land, and nearby tribes claimed a relationship with the individual, which they referred to as the "Ancient One", and demanded that the remains be reburied without being studied. Agreeing with the tribes and applying the Native American Graves Protection and Repatriation Act (NAGPRA), the U.S. Army Corps of Engineers seized the remains and halted all testing. Scientists claimed the right to study the remains, which 
they referred to as "Kennewick Man", under the Archaeological Resources Protection Act (ARPA), and brought suit challenging the Corps' legal conclusion that the remains qualified as Native American. The U.S. District Court found that the Corps had done inadequate analysis of difficult legal and factual issues, and remanded the matter for further consideration. The issue was transferred from the Corps to the Department of the Interior which also concluded that the remains were Native American within NAGPRA's meaning. The scientists returned to court, and the district court ruled in their favor to allow scientific study. The U.S. Court of Appeals affirmed, ruling that the remains were not Native American under NAGPRA, which requires that remains be "of, or relating to, a tribe, people, or culture that is indigenous to the United States". The court stressed that the relevant text is written in the present tense, and therefore the law requires that human remains bear a relationship to a presently existing tribe, people, or culture in order to be considered Native American, and there was insufficient evidence that the remains at issue were related to any current tribe. The court concluded that the remains should be transferred to the scientists who could proceed to study them under ARPA. Genetic testing failed to show that the remains belonged to a non-Native American, and the remains were ultimately transferred to and reburied by the tribes.

According to the Committee on Repatriation (1998) of the Society for American Archaeology (SAA), NAGPRA was intended to balance conflicting scientific and tribal interests. Goold \& Fanelli (2000; 2001), attorneys for the SAA, characterized this during litigation as "NAGPRA was intended to reasonably balance Native American interests in human remains and cultural items with those of the scientific community and the broader public", which goes even further in aligning the scientific and general public's interests against those of Native Americans. Barran \& Schneider (2001), attorneys for the scientists, made a number of incendiary legal arguments, including, for example, that the Wanapum tribe, which was part of the coalition, was not properly an "Indian tribe" because it was not federally recognized. They also argued for standards of affiliation which Native Americans would never be able to meet, including that determining "group identity" would require knowing the language, religious practices and customs, and interactions between groups thousands of years ago. They also argued that oral histories "are unstable over time and are not inherently reliable explanations of distant past events", and that the tribes "improperly used religious beliefs as proof of prehistoric events, and as a basis for denying [scientists] access to the skeleton, the discovery site, and government-held information" (Barran \& Schneider, 2001: p. 1, p. 12). They even went so far as to assert that oral histories that have metaphysical content cannot be used as evidence of past events without violating the U.S. Constitution, arguing:

Defendants hopelessly confused cultural information with religious beliefs ... Defendants repeatedly link religious stories with historical events, all in an effort to show that those religious beliefs point to a prehistory that is "true" for 
purposes of cultural affiliation. To use religious belief for such purposes violates the Establishment Clause (Barran \& Schneider, 2001: pp. 25-26).

In critiquing the case, Tsosie (2015) noted that the process was fraught with epistemic injustice. The courts were reluctant to acknowledge the harms asserted by the tribes but were fully accepting of the harms to scientific discovery and the public interest asserted by the scientists. The evidence offered by the tribes was discarded as religious mythology while the evidence offered by the scientists was fully respected, which "effectively reduces the Indigenous peoples to the status of religious zealots" (Tsosie, 2015: p. 1186). Writing on the broader issue of establishing cultural affiliation as a requirement for repatriation, Dumont (2011: p. 6) rejected the argument that Native American claims interfere with scientists' ability to represent "American interests" (and the implicit assertion that Native Americans are not Americans), and noted that "Native peoples continue to struggle with an entrenched assumption of colonial prerogative among American physical anthropologists and archaeologists". Thus, the Kennewick case illustrates the need for Indigenous archaeology and better relations between scientists and Indigenous peoples.

However, although the tribes' actual arguments were based largely on avoiding the desecration of remains belonging to an individual they believed to be their ancestor, the social and political issues of origins and claims to land were clearly present (Goldberg, 2006). As mentioned, Nicholas (2001) has admitted that there is a strong desire by some Indigenous peoples to use the archaeological record to support land claims. At least one commentator speculated that "the tribes fight against further testing of Kennewick Man is based largely on fear, fear that if someone else was here before they were, their status as sovereign nations and all that comes with it-treaty rights and lucrative casinos, like this one on the Umatilla Reservation-could be at risk" (Stahl, 2012, characterizing the position of James Chatters).

\section{Conclusion}

Certainly, the scientific endeavor would be greatly improved by increased communication and collaboration with and, perhaps most importantly, respect for all of its stakeholders. We support the goals of Indigenous archaeology to perform research that is "with", "by", and (in its reasonable form) "for" Indigenous peoples. However, there is great danger in extreme efforts to manipulate scientists and science to further social and political agendas and "the good" of decolonization. While well-intended, such an outcome-driven paradigm to further Indigenous interests is antithetical to and irreconcilable with the ideals of Western science, and is no more appropriate now to support counter-colonial agendas than it was in the past to support colonial agendas. Many of the historical examples relied upon by those attacking archaeology and other anthropological disciplines were ultimately rectified not by abandoning the ideals of Western science as unachievable but by intensifying efforts to more faithfully achieve 
them. Certainly, individual scientists are fallible and introduce bias, ignorance, and subjectivity into their research at every stage, but, over time, the consensus-seeking process works to correct much that results from individual weakness.

The misuse of science by colonials in the past should not become a justification for misusing it by or on behalf of Indigenous peoples in the present. Nevertheless, for Smith \& Jackson (2006: p. 341, emphasis added), the solution involves not an equalization but merely a transfer of control of the research process: "If colonialism has meant Indigenous peoples living within a framework of non-Indigenous control, the decolonization of archaeology has to involve archaeologists working within a framework of Indigenous controP'. So too for Custer (2005), and for McNiven \& Russell (2005: p. 236, emphasis added), who asserted that Indigenous communities "have every right to control archaeological research in whatever way they wish". For Steeves (2015: p 45, p. 85, emphasis added), "Political control of cultural information is critical to the survival and protection of Indigenous peoples' rights and sovereignty". For Smith \& Jackson (2006: p. 339) this means that Indigenous peoples "own" and have the exclusive right to determine how it is researched and reported, without regard to their motivations for exercising such control. For Nicholas (2001: p. 30), it seems to mean avoiding or suppressing research that "threatens the integrity of the [Indigenous] worldview and beliefs".

The slippery slope of scientific consequentialism is further manifested by a new extreme form of public archaeology which seeks to "make archaeology political again" (Gonzalez-Ruibal, Gonzalez, \& Criado-Boado, 2018: p. 513). This new paradigm seems to seek to transform archaeology into a tool of social critique to fight "reactionary populism" driven by nationalism, racism, and anti-intellectualism with the goal of reclaiming the privileges of an earlier, "better" time. What Gonzalez-Ruibal, Gonzalez, \& Criado-Boado (2018) have proposed arguably can be characterized as a left-wing archaeology to fight a right-wing movement. Their solution is "to go back to the roots of politics-radical dissent, conflict, inequality-and reconstruct archaeology as a public-engaged practice" (Gonzalez-Ruibal, Gonzalez, \& Criado-Boado, 2018: p. 514) to achieve broad consequentialist goals of serving what they perceive to be the social and political interests of all peoples.

Archaeology, being a human endeavor, will always suffer from imperfect objectivity. The response of extreme consequentialists is to abandon objectivity altogether and openly embrace subjectivity, but this response reflects the logical fallacy of the perfect solution (i.e., if we cannot achieve perfect objectivity, then there is no point in pursuing objectivity at all). Using archaeology to promote preferred agendas or ideologies has emotional appeal, but will only undermine overall respect for the discipline and trust in its results. While scientists can be advocates for positions derived from their research and results, they cannot let their personal preferences dictate their research or results or else they stop being 
scientists and become something else. We agree with McGhee's (2008) point that if archaeologists and other scientists are repentant for and concerned about being the unwitting pawns of colonial governments and their agendas, the solution is not to become the willing pawns of Indigenous governments and their agendas. The scientific study of Indigenous peoples can and should be improved by greater collaboration with its subjects and other stakeholders, but this can be achieved without abandoning the deontological ideals of the scientific method.

\section{Conflicts of Interest}

The authors declare no conflicts of interest regarding the publication of this paper.

\section{References}

Adovasio, J. M., \& Page, J. (2002). The First Americans: In Pursuit of Archaeology's Greatest Mystery. New York: Random House.

Arens, W. (1979). The Man-Eating Myth: Anthropology and Anthrophagy. New York: Oxford University Press.

Atalay, S. L. (2006). Indigenous Archaeology as Decolonizing Practice. American Indian Quarterly, 30, 280-310. https://doi.org/10.1353/aiq.2006.0015

Barran, P. A., \& Schneider, A. L. (2001). Memorandum in Support of Motion to Vacate Second Administrative Action. Bonnichsen et al. v. United States et al., United States District Court for the District of Oregon, April 16.

Barreiro, J. (1992). A Note on the Tainos. In J. Yewell, C. Dodge, \& J. DeSirey (Eds.), Confronting Columbus (pp. 30-47). Jefferson, NC: McFarland.

Billman, B. R., Lambert, P. M., \& Leonard, B. L. (2000). Cannibalism, Warfare, and Drought in the Mesa Verde Region during the Twelfth Century AD. American Antiquity, 65, 145-178. https://doi.org/10.2307/2694812

Cipolla, C. N., Quinn, J., \& Levy, J. (2019). Theory in Collaborative Indigenous Archaeology: Insights from Mohegan. American Antiquity, 84, 127-142.

https://doi.org/10.1017/aaq.2018.69

Colwell-Chanthaphonh, C. et al. (2010). The Premise and Promise of Indigenous Archaeology. American Antiquity, 75, 228-238. https://doi.org/10.7183/0002-7316.75.2.228

Committee on Repatriation (1998). SAA Position on the Kennewick Man Controversy. Washington DC: Society for American Archaeology, March 20.

Croes, D. R. (2010). Courage and Thoughtful Scholarship = Indigenous Archaeology Partnerships. American Antiquity, 75, 211-216.

https://doi.org/10.7183/0002-7316.75.2.211

Custer, J. F. (2005). Ethics and the Hyperreality of the Archaeological Thought World. North American Archaeologist, 26, 3-27. https://doi.org/10.2190/E0Y2-L9N8-43W0-RLT2

Deloria Jr., V. (1992). Indians, Archaeologists, and the Future. American Antiquity, 57, 595-598. https://doi.org/10.2307/280822

Deloria Jr., V. (1995). Red Earth, White Lies: Native Americans and the Myth of Scientific Fact. New York: Scribner.

Dongoske, K. E., Martin, D. L., \& Ferguson, T. J. (2000). Critique of the Claim of Cannibalism at Cowboy Wash. American Antiquity, 65, 179-190. 
https://doi.org/10.2307/2694813

Dumont, C. W. (2011). Contesting Scientists' Narrations of NAGPRA’s Legislative History Rule 10.11 and the Recovery of "Culturally Unidentifiable" Ancestors. Wicazo Sa Review, 26, 5-41. https://doi.org/10.1353/wic.2011.0009

Duran, E. (2006). Healing the Soulwound: Counseling with American Indians and Other Native Peoples. New York: Teachers College Press.

George, B. E. (2010). Who Am I and How Did I Get Here? In G. P. Nicholas (Ed.), Being and Becoming Indigenous Archaeologists (pp. 101-106). Walnut Creek, CA: Left Coast Press.

Gillespie, J. D. (2004). Review of Zimmerman, Larry J., Karen D. Vitelli and Julie Hollowell-Zimmer (2003). Canadian Journal of Archaeology, 28, 172-175.

Gnecco, C. (2011). Native Histories and Archaeologists. In C. Gnecco, \& P. Ayala (Eds.), Indigenous Peoples and Archaeology in Latin America (pp. 53-66). Walnut Creek, CA: Left Coast Press.

Goldberg, S. (2006). Kennewick Man and the Meaning of Life (pp. 275-288). Chicago, IL: University of Chicago Legal Forum.

Gonzalez-Ruibal, A., Gonzalez, P. A., \& Criado-Boado, F. (2018). Against Reactionary Populism: Towards a New Public Archaeology. Antiquity, 92, 507-515. https://doi.org/10.15184/aqy.2017.227

Goold, J. A., \& Fanelli, M. J. (2000). Memorandum in Support of Society for American Archaeology's Motion for Leave to Appear as Amicus Curiae. Bonnichsen et al. v. United States et al., United States District Court for the District of Oregon, December 11.

Goold, J. A., \& Fanelli, M. J. (2001). Memorandum of Law in Support of the Society for American Archaeology's Amicus Curiae Submission. Bonnichsen et al. v. United States et al., United States District Court for the District of Oregon, June 1.

Kilgour, M. (1998). The Function of Cannibalism at the Present Time. In F. Barker, P. Hulme, \& M. Iverson (Eds.), Cannibalism and the Colonial World (pp. 238-259). Cambridge: Cambridge University Press.

Kuper, A. (2003). The Return of the Native. Current Anthropology, 44, 389-402. https://doi.org/10.1086/368120

Lee, L. L. (2010). Navajo Transformative Scholarship in the Twenty-First Century. Wicazo Sa Review, 25, 35-45. https://doi.org/10.1353/wic.0.0055

Louis, R. P. (2007). Can You Hear Us Now? Voices from the Margin, Using Indigenous Methodologies in Geographic Research. Geographical Research, 45, 130-139. https://doi.org/10.1111/j.1745-5871.2007.00443.x

McGhee, R. (2008). Aboriginalism and the Problems of Indigenous Archaeology. American Antiquity, 73, 579-597. https://doi.org/10.1017/S0002731600047314

McNiven, I. J. (2016). Theoretical Challenges of Indigenous Archaeology: Setting an Agenda. American Antiquity, 81, 27-41. https://doi.org/10.7183/0002-7316.81.1.27

McNiven, I. J., \& Russell, L. (2005). Appropriated Pasts: Indigenous Peoples and the Colonial Culture of Archaeology. Lanham, MD: AltaMira.

Morrow, D. C., \& Lekson, S. (1999). Ancestral Guilt. Archaeology, 53, 5-6.

Nicholas, G. P. (2001). The Past and Future of Indigenous Archaeology: Global Challenges, North American Perspectives, Australian Prospects. Australian Archaeology, 52, 29-40. https://doi.org/10.1080/03122417.2001.11681703

Nicholas, G. P. (2008). Native Peoples and Archaeology. In D. M. Pearsall (Ed.), Encyc- 
lopedia of Archaeology (Volume 3, pp. 1660-1669). New York: Elsevier. https://doi.org/10.1016/B978-012373962-9.00203-X

Nicholas, G. P., \& Andrews, T. D. (1997). At a Crossroads: Archaeology and First Peoples in Canada. Burnaby: Archaeology Press.

Rigney, L.-I. (1999). Internationalization of an Indigenous Anticolonial Cultural Critique of Research Methodologies: A Guide to Indigenist Research Methodology and Its Principles. Wicazo Sa Review, 14, 109-121. https://doi.org/10.2307/1409555

Shipley, G. P., \& Williams, D. H. (2019). Limitations of the Western Scientific Worldview for the Study of Metaphysically Inclusive Peoples. Open Journal of Philosophy, 9, 295-317. https://doi.org/10.4236/ojpp.2019.93020

Silliman, S. W. (2008). Collaborating at the Trowel's Edge: Teaching and Learning in Indigenous Archaeology. Tucson, AZ: University of Arizona Press.

Silliman, S. W. (2010). The Value and Diversity of Indigenous Archaeology: A Response to McGhee. American Antiquity, 75, 217-220. https://doi.org/10.7183/0002-7316.75.2.217

Smith, C., \& Jackson, G. (2006). Decolonizing Indigenous Archaeology. American Indian Quarterly, 30, 311-349. https://doi.org/10.1353/aiq.2006.0032

Smith, L. (2004). Archaeological Theory and the Politics of Cultural Heritage. London: Routledge. https://doi.org/10.4324/9780203307991

Stahl, L. (2012). Kennewick Man. 60 Minutes. CBS, September 25.

Steeves, P. F. (2015). Decolonizing Indigenous Histories, Pleistocene Archaeology Sites of the Western Hemisphere. PhD Dissertation, Binghamton, NY: Department of Anthropology, State University of New York.

Trigger, B. G. (1997). Foreword. In G. P. Nicholas, \& T. D. Andrews (Eds.), At a Crossroads: Archaeology and First Peoples in Canada (pp. 7-13). Burnaby: Archaeology Press.

Tsosie, R. (2015). Indigenous Peoples and Epistemic Justice: Science, Ethics, and Human Rights. Washington Law Review, 87, 1133-1201.

Ucko, P. J. (2001). Indigenous Archaeology at the Institute of Archaeology. Papers from the Institute of Archaeology, 12, 1-11. https://doi.org/10.5334/pia.168

Waters, M. R., \& Stafford Jr., T. W. (2014). The First Americans: A Review of the Evidence for the Late-Pleistocene Peopling of the Americas. In K. E. Graf, C. V. Ketron, \& M. R. Waters (Eds.), Paleoamerican Odyssey (pp. 541-560). College Station, TX: Texas A\&M University Press.

Watkins, J. E. (2003). Beyond the Margin: American Indians, First Nations, and Archaeology in North America. American Antiquity, 68, 273-285.

https://doi.org/10.2307/3557080

Watkins, J. E. (2005). Artefacts, Archaeologists and American Indians. Public Archaeology, 4, 187-191. https://doi.org/10.1179/146551805793156211

Watkins, J. E. (2010). Indigenous Archaeology as Complement to, Not Separate From, Scientific Archaeology. Jangwa Pana, 10, 46-62.

White Deer, G. (1998). Return of the Sacred: Spirituality and the Scientific Imperative. In D. S. Whitely (Ed.), Reader in Archaeological Theory: Post-Processual and Cognitive Approaches (pp. 331-338). New York: Routledge.

Wilcox, M. (2010). Saving Indigenous Peoples from Ourselves: Separate But Equal Archaeology Is Not Scientific Archaeology. American Antiquity, 75, 221-227.

https://doi.org/10.7183/0002-7316.75.2.221 
Wilson, S. (2008). Research Is Ceremony: Indigenous Research Methods. Halifax: Fernwood Publishing.

Wobst, M. H. (2010). Power to the Indigenous Past and Present! Or: The Theory and Method behind Archaeological Theory and Method. In M. Burchac, S. M. Hart, \& H. M. Wobst (Eds.), Indigenous Archaeologies: A Reader on Decolonization (pp. 76-78). Walnut Creek, CA: Left Coast Press.

Zimmerman, L. J., Vitelli, K. D., \& Hollowell-Zimmer, J. (2003). Ethical Issues in Archaeology. Walnut Creek, CA: AltaMira. 